\title{
Managing the challenging pediatric airway: Continuing Professional Development
}

\author{
Cengiz Karsli, MD
}

Received: 8 January 2015/Accepted: 15 June 2015/Published online: 5 August 2015

(c) Canadian Anesthesiologists' Society 2015

\begin{abstract}
Purpose This module will give the anesthesia provider the information needed to identify, prepare for, and clinically manage a difficult airway in children.

Principal findings Although the incidence of difficult intubation is lower in children than in adults, the anesthesiologist who even occasionally cares for children must be prepared to manage the pediatric patient with a known or suspected difficult airway. Many of the predictors of a difficult intubation that are useful in adults do not apply to children. Predictably, many children with a challenging airway also have a syndrome or diagnosis known to be associated with difficult intubation.

Due to the unique emotional, physiological, and anatomical characteristics of small children, the approach to airway management is different from that in adults. Awake intubation is almost never an option, and recently, there has been a trend towards using cuffed tracheal tubes and apneic intubation. The flexible fibrescope has seen less action as the sole intubating device with the recent introduction of the various video laryngoscopes designed for pediatric use. Supraglottic airways are now being used in children with a difficult airway, not only as a rescue device in the event of failed intubation but also as a first-choice airway device and as a conduit for tracheal intubation.
\end{abstract}

Electronic supplementary material The online version of this article (doi:10.1007/s12630-015-0423-y) contains supplementary material, which is available to authorized users.

C. Karsli, MD ( $ه)$

Department of Anesthesia, The Hospital for Sick Children,

Toronto, ON, Canada

e-mail: cengiz.karsli@sickkids.ca
Conclusion Although direct laryngoscopy can still be used to manage the care of the majority of children with a known or suspected challenging airway, there is now a noticeable trend towards the use of a supraglottic airway and apneic intubation using fibreoptic and video laryngoscopic equipment.

\section{Objectives of this Continuing Professional Development (CPD) module:}

After reading this module, the anesthesia provider should be able to:

1. Describe the clinically relevant differences between the pediatric and adult airway;

2. Identify predictors of a difficult pediatric airway;

3. Conduct the safe anesthetic management of a child with a difficult airway;

4. Formulate a plan in the event of an unanticipated difficult intubation or a failed tracheal intubation in a child.

Most non-pediatric anesthesiologists are comfortable caring for children over eight years of age provided there are no significant comorbidities. A suspected difficult airway is probably the single most worrisome coexisting condition affecting this comfort level. This continuing professional development module will help the anesthesia provider to identify a challenging airway in pediatric patients and to plan for anesthetic induction in such cases.

\section{Unique characteristics of the pediatric airway}

The anatomy of a child's airway has unique features that may pose a challenge for both bag-mask ventilation and 
Table 1 Anatomic features unique to the pediatric airway, their clinical implications, and suggested management strategies

\begin{tabular}{lll}
\hline Anatomic Feature & Implication & Management \\
\hline Prominent occiput & $\begin{array}{l}\text { Neck flexed in supine position } \\
\text { Upper airway obstruction likely } \\
\text { Oral/pharyngeal/laryngeal axes are not lined up, making } \\
\text { laryngoscopy difficult. }\end{array}$ & Shoulder roll for infants (see Fig. 1) \\
& $\begin{array}{l}\text { Larynx seems more anterior. } \\
\text { Entire tongue is in oral cavity, increasing risk of obstruction. }\end{array}$ & $\begin{array}{l}\text { Lateral approach to laryngoscopy } \\
\text { Oral arway to relieve obstruction. } \\
\text { Cephalad larynx }\end{array}$ \\
$\begin{array}{l}\text { Epiglottis angled over } \\
\text { vocal cords }\end{array}$ & Epiglottis often obstructs view of vocal cords. & $\begin{array}{c}\text { Straight laryngoscope blade in children under 3 } \\
\text { years of age. }\end{array}$ \\
\hline
\end{tabular}
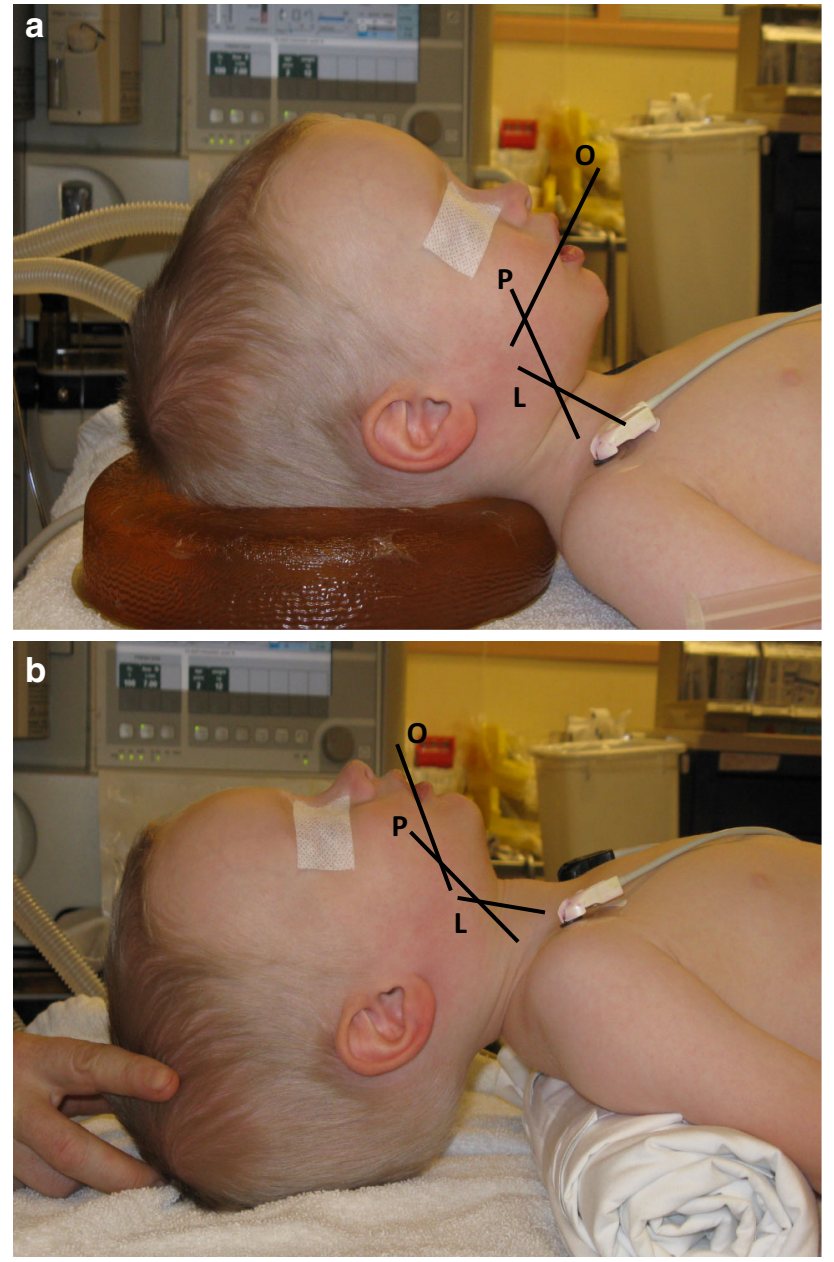

Fig. 1 A roll inserted under the shoulders of the infant will help line up the oral $(\mathrm{O})$, laryngeal $(\mathrm{L})$, and pharyngeal $(\mathrm{P})$ axes making direct laryngoscopy easier

Un rouleau placé sous les épaules du nourrisson permettra d'aligner les axes oral $(\mathrm{O})$, laryngé $(\mathrm{L})$ et pharyngé $(\mathrm{P})$, facilitant ainsi la laryngoscopie directe

tracheal intubation. These anatomic differences are outlined in Table 1 (Fig. 1).

In addition, there are physiologic and emotional characteristics of the pediatric patient that may affect airway management. A higher metabolism and oxygen consumption rate means that oxygen desaturation occurs more rapidly in infants and small children in the presence of apnea. The typical child will be anxious, frightened, or uncooperative. The child who is crying or screaming on induction will desaturate even more quickly. For this reason, preoperative sedation and/or parental presence for induction is often beneficial, even in the presence of a known difficult airway. ${ }^{1}$

Common pitfalls might be encountered even in routine pediatric airway management, particularly by the nonpediatric anesthesiologist. One of the most frequent mistakes is late recognition of an upper airway obstruction. Care must be taken to ensure the child's airway is indeed patent during anesthetic induction. With an upper airway obstruction, the compliant chest wall will be seen to move vigorously during spontaneous respiration. The following indications should prompt an immediate response to relieve the obstruction: tracheal tug, paradoxical chest wall movement, and the absence of movement of the anesthetic breathing bag or capnograph tracing. In many cases, the obstruction will be relieved by applying a proper jaw thrust using a two-handed technique with an anterior thrust at the head (and not the angle) of the mandible. Improper application of a jaw thrust in a small child may worsen the obstruction by forcing the child's tongue against the hard and soft palates (see Video 1, available as Electronic Supplementary Material).

Another common mistake is inadequate anesthetic depth during mask induction or airway manipulation. The partly anesthetized child will struggle, breath-hold, and have partial airway obstruction, leading to rapid oxygen desaturation. Insertion of an oral airway at a light plane of anesthesia may also lead to laryngospasm and breathholding. A deeper plane of anesthesia allows for easier insertion of the oral airway to relieve the obstruction and to assist or take over ventilation. Overly aggressive bag-mask ventilation, particularly at a light anesthetic depth, may lead to gastric insufflation, reducing lung volumes and increasing the risk of regurgitation. An inadequately sized oral airway may be a contributing factor; when a correctly 
sized oropharyngeal airway is placed at the side of the child's face, it will extend from the lips to the angle of the mandible. Nasopharyngeal airways are sized from the tip of the nose to the tragus of the ear.

\section{Predicting difficulty in pediatric airway management}

The incidence of difficult intubation in children varies from less than $0.1 \%$ to more than $3.5 \%$ depending on the reference source. ${ }^{2}$ In most centres, the incidence is highest in the infant age group (less than one year of age) ${ }^{3}$ and in patients with congenital cardiac anomalies. ${ }^{4}$ In a recent single-centre study, the incidence of difficult laryngoscopy was found to be $0.68 \%$, with infants under one year of age and teenagers with craniofacial anomalies representing the majority of cases. ${ }^{5}$ In any case, it is agreed that the incidence of difficult intubation in children is less than that seen in adults. Fortunately, the majority of difficult airways in children are predictable based on history and physical examination. Many children with a history of difficult intubation have a syndrome known to be linked to a challenging airway. Table 2 lists some of the more common conditions associated with difficult intubation in children. Although laryngoscopy becomes less difficult in many of these cases as the child grows, there are noticeable exceptions, including Goldenhar syndrome and the mucopolysaccharidoses, where the airway may become more difficult with age. ${ }^{6}$ In cooperative children more than four years of age, the Mallampati score has been shown to correlate with the Cormack-Lehane laryngoscopic view. ${ }^{7}$ Nevertheless, the majority of children in that age group will not cooperate in this manner, and as such, most practitioners consider the Mallampati classification to be of little use in children. ${ }^{8}$ A more useful assessment tool simply involves observing the child in profile and looking for a recessed or smaller than normal mandible ${ }^{2}$ (Fig. 2). Other features associated with difficult laryngoscopy include a limited mouth opening, prominent dentition, facial asymmetry with ear deformities, and a cleft palate. ${ }^{9}$

\section{Anesthetic management}

\section{Preparation}

Regardless of the planned method of induction and airway management, adequate preparation of both the patient and the equipment is essential. A difficult airway cart should be readily available and properly stocked with a variety of laryngoscope blades, supraglottic airways (SGA), tracheal tube guides, oral and nasal airways, and fibreoptic and video laryngoscopic instruments. ${ }^{10}$ Eliciting the help of an
Table 2 Syndromes and conditions commonly associated with a difficult airway

\begin{tabular}{ll}
\hline Goldenhar & Juvenile arthritis \\
Pierre Robin & Cleft palate \\
Treacher Collins & Trauma/Burn \\
Arthrogryposis & Oral Tumour \\
Apert & Klippel-Feil \\
Trisomy 21(Down) & Mucopolysaccharidosis \\
\hline
\end{tabular}

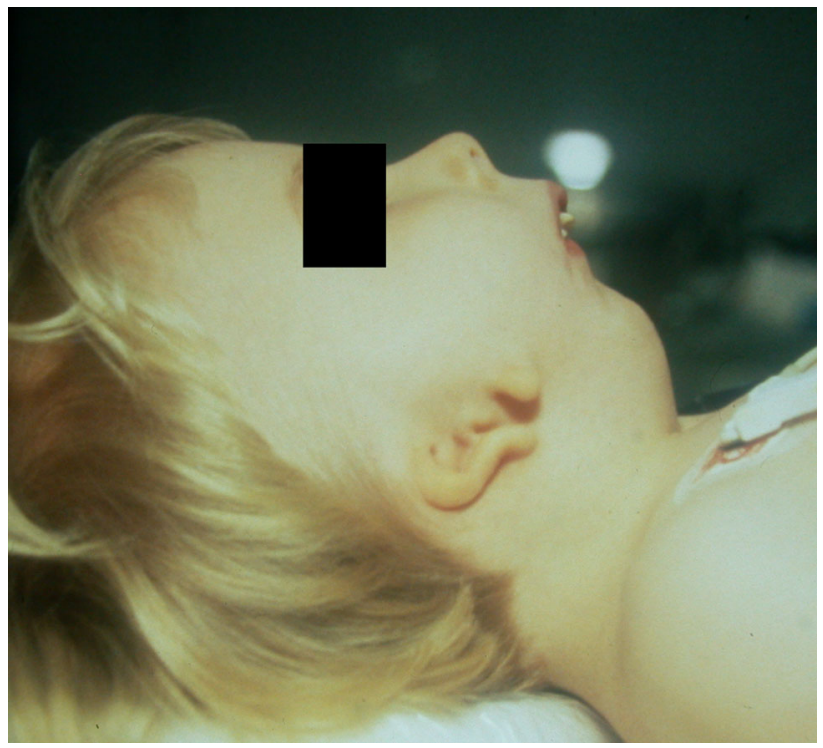

Fig. 2 Observation of the child in profile for features such as micrognathia or retrognathia is a useful technique to help identify a potential difficult intubation. Congenital ear malformations may also be associated with challenging airways in children

L'observation de l'enfant de profil pour identifier des caractéristiques telles qu'une micrognathie ou une rétrognathie est utile pour détecter une intubation potentiellement difficile. Les malformations congénitales des oreilles peuvent aussi être associées à des difficultés dans l'abord des voies aériennes de l'enfant

experienced assistant is just as important as having a full complement of airway instruments. If at all possible, the patient with a difficult airway should have intravenous access secured prior to induction, provided attempts at vascular access do not cause undue distress and aggravate an already precarious airway. This may be facilitated with topical local anesthetics, such as EMLA ${ }^{\circledR}$ or Ametop ${ }^{\mathrm{TM}}$, and judicious doses of anxiolytics provided the patient is adequately monitored. ${ }^{11}$ Midazolam $0.5-1 \mathrm{mg} \cdot \mathrm{kg}^{-1}$ along with acetaminophen $10-15 \mathrm{mg} \cdot \mathrm{kg}^{-1}$ (which hides the bitter taste of midazolam) given orally will take effect in about $15 \mathrm{~min}$. Infants weighing less than $15 \mathrm{~kg}$ may benefit from intranasal midazolam spray $0.2-0.3 \mathrm{mg} \cdot \mathrm{kg}^{-1}$, which works in five minutes. The intranasal midazolam solution should be undiluted and as concentrated as possible to minimize the volume administered. Anticholinergic agents, such as 
atropine or glycopyrrolate, should be considered both for their antisialagogue properties and to avoid bradycardia associated with anesthetic induction and laryngoscopy. ${ }^{12}$

Prior to entering the operating room (OR), the anesthesiologist will have established a mental blueprint of the induction sequence. It is vital to have an anesthetic induction plan as well as a back-up plan and to communicate this plan to the entire OR team. In case of a potentially very difficult airway problem, it may also be judicious to communicate with the otolaryngologist in advance.

\section{Induction strategies}

Maintaining adequate oxygenation and ventilation throughout the intubation sequence is essential. Since oxygen desaturation occurs very rapidly in small children who are rendered apneic, maintaining spontaneous respiration for tracheal intubation has been the classic teaching in difficult airway management. A nasopharyngeal airway or small tracheal tube inserted in the nasopharynx can act as an oxygen (and anesthetic vapour) conduit during intubation attempts. In infants and small children, high-flow oxygen delivery at $2-5 \mathrm{~L} \cdot \mathrm{min}^{-1}$ via nasal prongs has been shown to provide apneic oxygenation, buying crucial time needed to secure the airway. ${ }^{12}$ The decision to maintain spontaneous respiration for intubation will depend on patient factors, institutional practice, and personal preference. Conditions such as intraoral or mediastinal tumours, epiglottitis, airway foreign bodies, and a severely limited mouth opening may be associated with difficult or risky bagmask ventilation. In these patients, it may be wise to delay positive pressure ventilation and muscle relaxation until the airway is secured and/or the obstruction is relieved. Anesthetic induction may be achieved with sevoflurane inhalation, intravenous anesthetic infusion, or a combination of both. Propofol, ketamine, midazolam, and remifentanil may be used in a variety of combinations for this purpose.

Increasingly, there has been a trend towards apneic and even muscle-relaxed tracheal intubation when managing a difficult airway in children, provided bag-mask ventilation is easy. This is due in part to the introduction of the various video laryngoscopes for pediatric use. When the flexible fibreoptic bronchoscope was the only device available, maintaining spontaneous respiration for tracheal intubation was the logical approach. When compared with direct laryngoscopy, video laryngoscopy may allow for faster visualization of the glottis and may yield a better view and a higher rate of successful intubation in children with a difficult airway. ${ }^{13}$ These devices have given anesthesiologists the confidence to render the child with a difficult airway apneic for intubation. As with any intubation device, anesthesiologists should be very experienced with its use in children with a normal airway

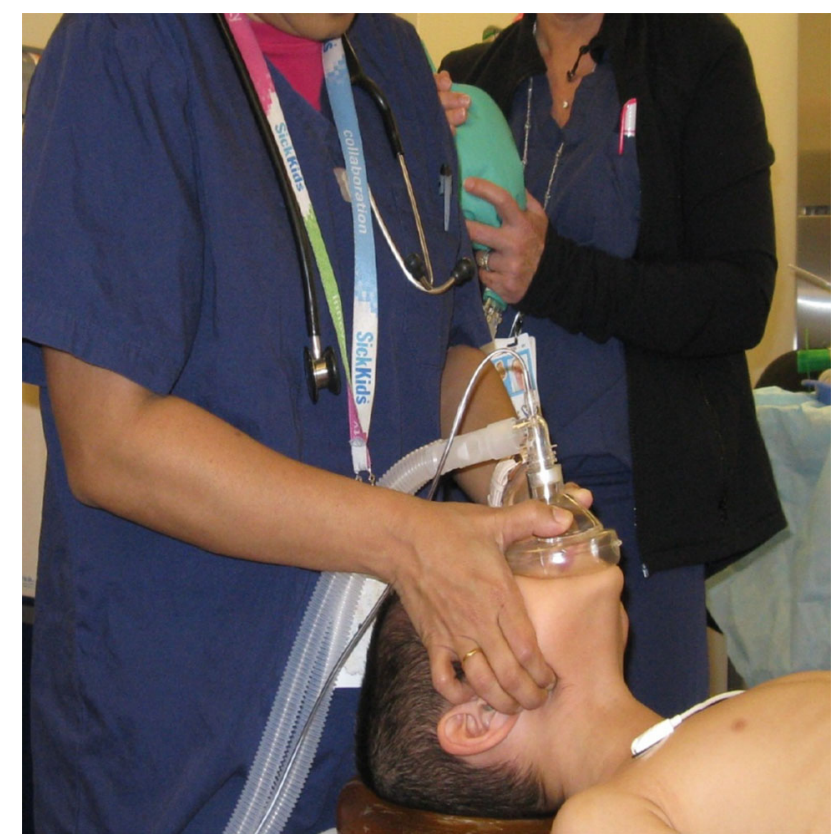

Fig. 3 Technique of two-person bag-mask ventilation in a child Technique de ventilation au masque à deux personnes chez l'enfant

before using it in children with a difficult airway. The author favours apneic intubation, provided bag-mask ventilation is straightforward and it is not for the abovementioned conditions in which muscle relaxation may be risky. One must always be prepared to maintain oxygenation and positive pressure ventilation in the event tracheal intubation proves unsuccessful. To this end, the two-person technique of bagmask ventilation (see Fig. 3) should be applied between attempts, and appropriately sized oral and SGA rescue devices should be available.

Use of sugammadex could further influence anesthesiologists' approach when caring for children with a difficult airway. Sugammadex is currently marketed for use in over 40 countries, and reports have shown that it can rapidly reverse deep rocuronium paralysis in children. ${ }^{14}$ To date, however, sugammadex is not licensed for use in Canada partly due to its prohibitive cost. It is estimated to cost more than $\$ 540$ to reverse deep rocuronium block in the typical adult.

Although there is a vast and growing selection of pediatric fibreoptic and video laryngoscopic intubating devices available on the market, the majority of tracheal intubations in children with a difficult airway can be achieved using direct laryngoscopy. The two-person technique for tracheal intubation involves one person performing laryngoscopy and manipulating the larynx into view while the second person looks over the shoulder of the laryngoscopist and inserts the styletted tracheal tube. This technique requires no special or expensive equipment and 
has a very high success rate when performed by experienced personnel (Fig. 4). It is a very useful technique to master as a back-up intubation strategy or in the event that fibreoptic or video laryngoscopic equipment is not available.

\section{Cuffed vs uncuffed tracheal tubes}

Over the last decade, there has been a clear trend towards using cuffed tracheal tubes in children. This is due largely to the advent of low-pressure high-volume cuffs. A recent review confirmed the increasing domination of cuffed tubes in pediatric anesthetic practice. ${ }^{15}$ Their use has also been shown to decrease the need for multiple intubations, reduce costs, and exhibit a low side-effect profile. It is undesirable to guess at the tracheal tube size in a child with a difficult airway, particularly if there is a chance that the tube will be too large to fit through the cricoid cartilage. As such, the tendency is to favour the slightly smaller tube, which further highlights the advantage of using a cuffed tube in these children. The only disadvantage to this approach is that a smaller tube may require a smaller more flimsy stylet and a smaller flexible fibrescope with its inferior optics.

\section{Airway devices}

A staggering number of airway devices adapted for pediatric use are now available on the market. Virtually all the devices are scaled-down versions of instruments originally designed for use in adults. They include SGAs, combined laryngoesophageal tubes, flexible fibrescopes, video and optical laryngoscopes, and lighted fibreoptic stylets. Some are fragile and require frequent servicing, and all are relatively expensive. There is a trend towards trainees being encouraged to reach for one of these devices rather than for a direct laryngoscope. This may be understandable given the added teaching potential afforded by having a viewing screen for both student and teacher. Any device, however, has an associated learning curve, and a novice should be taught the proper technique of jaw thrust and bag-mask ventilation specific to pediatrics. Since some centres may not have these newer intubating devices, direct laryngoscopy should remain a vital part of any pediatric airway management training program. The following sections outline the salient differences in the management of the difficult pediatric airway using a variety of airway devices.

\section{Supraglottic airways}

Every experienced anesthesiologist has probably used an SGA to care for a patient with a known difficult airway. These devices have revolutionized anesthetic practice and
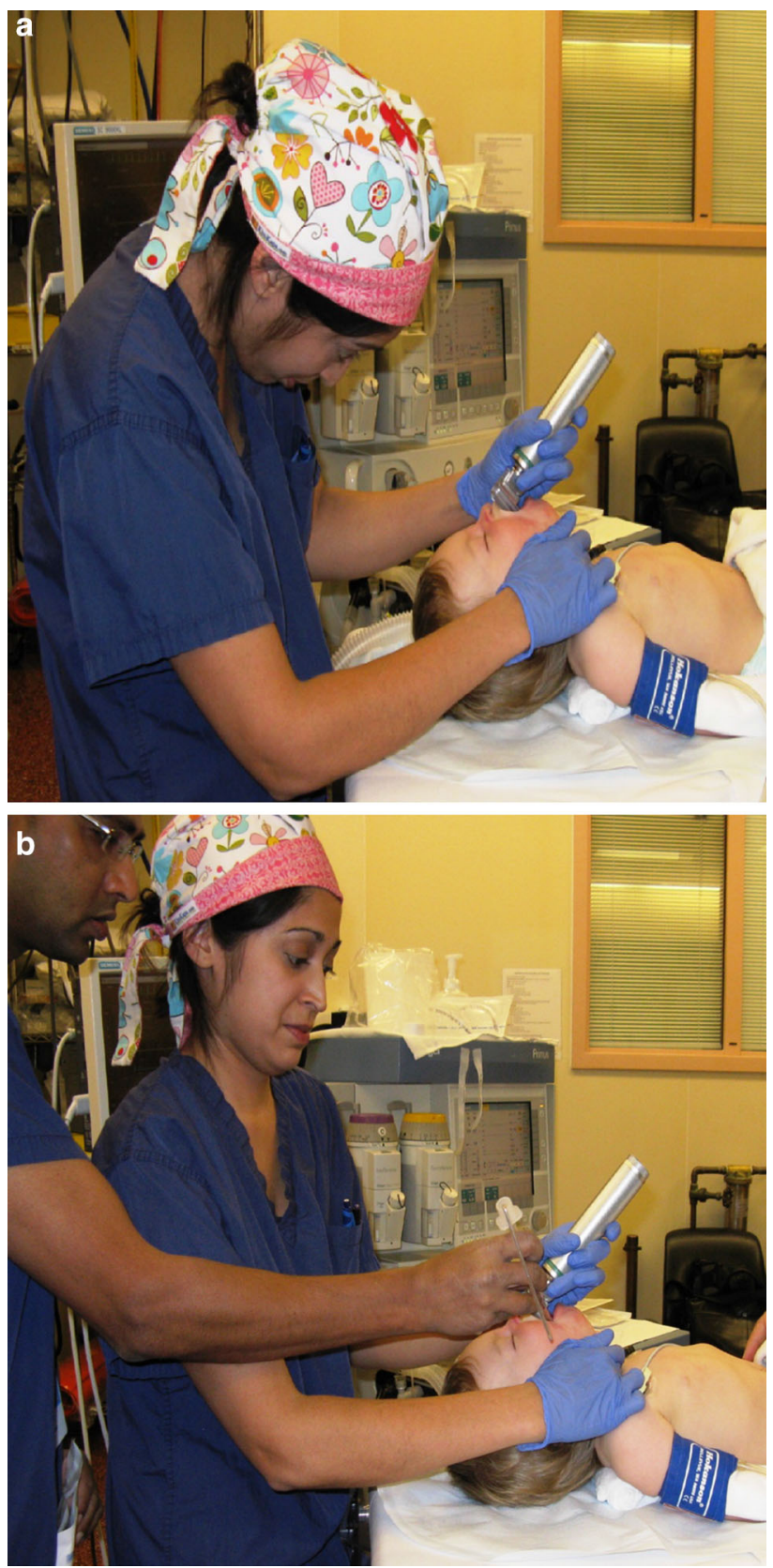

Fig. 4 Two-person technique of intubation using direct laryngoscopy. The laryngoscopist manipulates the larynx into the best possible view (a) while a second person directs the styletted tube through the vocal cords (b)

Technique à deux personnes d'intubation par laryngoscopie directe. La personne réalisant la laryngoscopie manipule le larynx pour obtenir la meilleure vision (a) alors que la seconde personne insère la sonde avec stylet entre les cordes vocales (b)

deservedly claim a very important role in every difficult airway algorithm. An SGA may be the best first choice for airway management in the child with a known or suspected difficult airway provided there is good access to the airway at all times, ventilation and oxygenation are easily maintainable, and a clear back-up airway plan is 
formulated and communicated to the entire OR team. Ideally, the surgical case should involve a peripheral part of the body and be of short duration. It should not lead to significant fluid shifts and should be performed in the supine position. An SGA is probably not the best choice for patients with an airway obstruction beyond the glottis, those needing high airway pressure, or those at an increased risk of pulmonary aspiration. ${ }^{16}$ Many of the newer models are designed with a larger diameter tube, shorter shaft, and gentler angle to allow for intubation through the lumen of the airway. In a large retrospective single-centre study, an SGA was a first choice for managing a difficult airway in more than $23 \%$ of children. Alternative airways were eventually needed in only four of those patients; in two patients, the SGA was replaced with an SGA of a different size, and in the other two patients, the SGA acted as the conduit for fibrescope tracheal intubation. ${ }^{17}$ If possible, the sequence of performing fibrescope intubation through an SGA should be practiced on a mannequin before attempting the procedure for the first time in a child. The sequence requires multiple coordinated steps that cannot be interrupted or delayed, and it is further complicated if a cuffed tracheal tube is used. The technique of fibreoptic intubation through an SGA in children has been described elsewhere. ${ }^{1}$ It is often easier to perform fibreoptic intubation through an SGA if the patient is apneic and at a deep plane of anesthesia (or even paralyzed) the moment the fibrescope passes through the vocal cords. The clinician may assess the view through the fibrescope as it reaches the distal aperture of the SGA, and if the glottic opening is in plain view, the patient may then be paralyzed or taken to a deeper anesthetic plane to minimize the chance of laryngospasm or coughing as the scope passes through the cords. If, however, the vocal cords are not immediately in front of the SGA aperture, the position of the SGA should be adjusted in order to afford an unobstructed view of the glottic opening. Attempting to snake through a sinusoidal path from SGA aperture to glottis will reduce the likelihood of easily railroading the tracheal tube over the fibrescope.

\section{Direct laryngoscopes}

Since a difficult airway in the vast majority of children can be managed with direct laryngoscopy, its mastery is the second most important skill to acquire (the first being proper jaw thrust and bag-mask ventilation in children). The size of the patient's mandible rather than the patient's age or weight must be considered when choosing the size of laryngoscope blade. An18-yr-old patient weighing $80 \mathrm{~kg}$ with Goldenhar syndrome and severe micrognathia will be best served by a laryngoscope blade appropriate to the size of the mandible, which often means an infant blade. In fact, of all the sizes and shapes of different blades, the size 1 straight blade (i.e., meant for infants) will often yield the best laryngoscopic view in the micrognathic/retrognathic patient. The blade is inserted into the extreme right side of the mouth and is not swept to the midline as it is in adults. This keeps the tongue to the left of the blade at all times and prevents the incisor or canine teeth from obscuring the view (Fig. 5). It may be helpful to have an assistant pull back the right corner of the child's mouth with a small retractor (e.g., Senn retractor) to increase the space for tracheal tube placement. The tube should be styletted either straight or in a hockey stick configuration. Ideally, any case
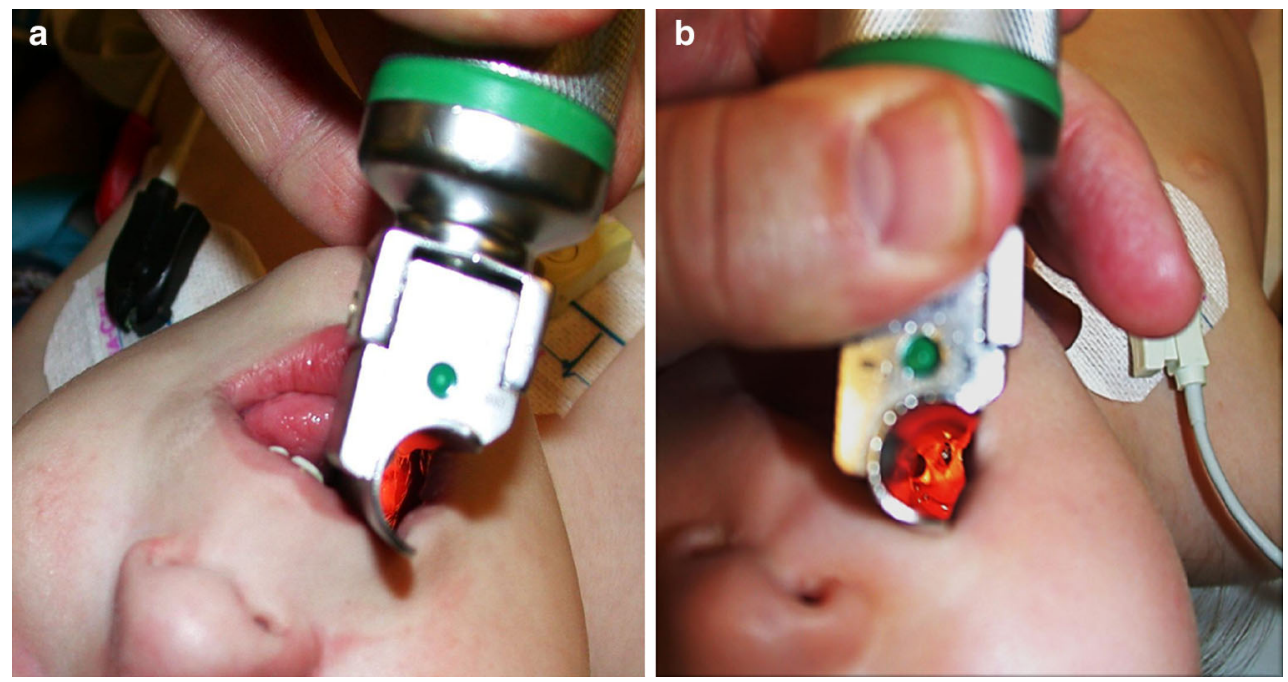

Fig. 5 The lateral approach to direct laryngoscopy in a child Approche latérale pour la laryngoscopie directe chez l'enfant 
of difficult intubation should be managed with a twoperson technique as described previously.

Intubating introducers (bougies)

Although there are case reports describing successful intubation using the bougie in children, ${ }^{18}$ its value in pediatric difficult airway management is inferior to that in adult practice. The smaller diameter of the pediatric bougies makes them undesirably flimsy. In infants and small children, it is almost impossible to feel the anterior coudé tip bouncing off the tracheal rings as it is advanced down the trachea. This means that the bougie cannot be used as intended; instead, it is inserted under the laryngoscope blade down the oropharynx. If resistance is encountered at an insertion distance estimated to be at the level of the carina, the bougie might be in the trachea. If no resistance is encountered, then the introducer has likely been placed in the esophagus. Many anesthesiologists are somewhat uncomfortable using a blind technique to intubate the child's trachea when there are other options that allow visualization of the glottis.

\section{Video laryngoscopes}

A number of these devices exist for pediatric and infant use. Most anesthesiology trainees are very familiar with their use in adults, and many of the skills needed to be proficient in video laryngoscope intubation in adults translate to pediatric use, with a few stipulations. Since the small child will desaturate quickly with apnea, inserting the styletted tracheal tube in the right side of the mouth towards the hypopharynx prior to video laryngoscope insertion may be very useful in two ways. First, it will decrease the risk of being unable to insert the tracheal tube into the oropharynx during video laryngoscopy, a common problem encountered in adult practice. Second, it will save precious seconds needed to advance the tracheal tube tip close to the larynx, as it will likely already be in the vicinity when the video laryngoscope is inserted (Video 2, available as Electronic Supplementary Material). Although manufacturers of these scopes recommend a stylet in the shape of the blade, many prefer a hockey stick configuration. In the event of a very anterior larynx or severe retro/micrognathia, exaggeration of the hockey stick bend to greater than $90^{\circ}$ has proven to be helpful (Fig. 6). The largest and stiffest stylet available that fits into the tracheal tube should be used, as a flimsy stylet is of little use. Another helpful trick is to create as much space as possible between the viewing tip and the vocal cords. This allows the styletted tracheal tube more maneuverability in the viewing area close to the glottis. The video laryngoscope is inserted in the midline, and when a glottic view is obtained, the laryngoscopist should pull the scope as

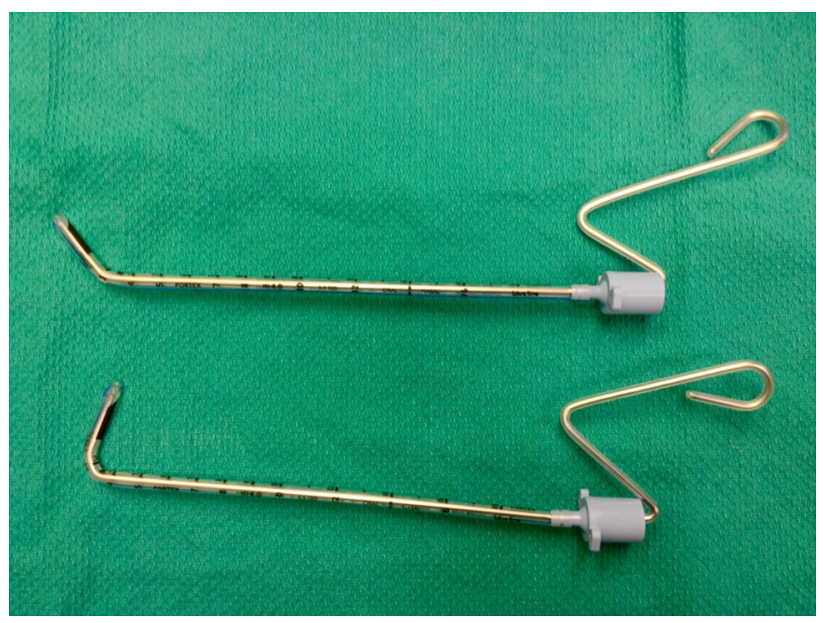

Fig. 6 Options for configuration of a tracheal tube stylet for use during video laryngoscopy. A hockey stick shape (top) is useful and may be exaggerated (bottom) in the event of severe retro or micrognathia Configuration $\mathrm{du}$ stylet pour la sonde trachéale durant la vidéolaryngoscopie. Une forme en bâton de hockey (en haut) est utile et peut être exagérée (en bas) en cas de rétro- ou micrognathie sévère

cephalad as possible to create the working room necessary to manipulate the tracheal tube tip into the glottis.

Another desirable use of the video laryngoscope is to facilitate flexible fibrescope intubation either for teaching purposes or in the event that video laryngoscope or flexible fibrescope intubation are unsuccessful. Those who have a particular interest in difficult airway management uniformly embrace this technique, which requires coordinated effort by experienced personnel who have practiced this maneuver in normal airways. In this case, the light source and view both originate from the video laryngoscope, and the fibrescope simply becomes a very expensive adjustable stylet (Video 3, available as Electronic Supplementary Material).

\section{Flexible fibrescopes}

Despite the barrage of numerous video and optical laryngoscopes onto the market, the flexible fibrescope will likely retain its place in every anesthetic department for a long time to come. As mentioned above, it may be combined with other airway devices to maximize the success of intubation. In addition, there will forever be the occasional need to look down the end of a tracheal tube for diagnostic or therapeutic measures. Flexible fibreoptic bronchoscopy remains the difficult airway intubation method of choice for many anesthesiologists who have become masters in the art.

There are many suggested tricks to ensure safe and rapid tracheal intubation using a flexible fibrescope. First, adequate oxygenation should be ensured throughout the process. As mentioned above, a small tracheal tube placed 
in the nasopharynx may serve as a conduit for oxygen and anesthetic gases in a spontaneously breathing child. Alternatively, high-flow oxygen via nasal prongs will at least temporarily provide adequate oxygenation whether the patient is breathing or is apneic. Commercially prepared intubating masks allow for continued positive pressure ventilation while performing an oral or nasal intubation (Fig. 7). Regardless of the approach, it is always beneficial to advance the tip of the fibrescope down the pharynx and through the cords as rapidly as possible. This is particularly true if apneic intubation has been chosen. With the tracheal tube loaded on the fibrescope and the assistant providing lung ventilation, the fibrescope is placed at the side of the patient's face with the tip flexed anteriorly. The anesthesiologist holds the fibrescope at a level where its tip will be at the vocal cords (roughly the angle of the mandible), his index finger and thumb grasping the the fiberscope at the point where the fingers touch the patient's lips (for oral intubation) or nostril (for nasal intubation). The scope is then placed in the patient's mouth or nose, directed midline with anterior flexion at the tip, and advanced rapidly until the anesthesiologist's fingers make contact with the patient. It is only then that the anesthesiologist looks at the viewing screen to make final position adjustments for the tube tip to enter the glottis. With this approach, the time to advance from surface to vocal cords is minimized. With a bit of practice, this technique can allow for tracheal intubation in just a few seconds. Videos 4 and 5 illustrate this technique in a mannequin and in a child (available as Electronic Supplementary Material).

The unanticipated difficult airway

In the event of an unanticipated difficult intubation, the anesthesiologist must act quickly and calmly and solicit the

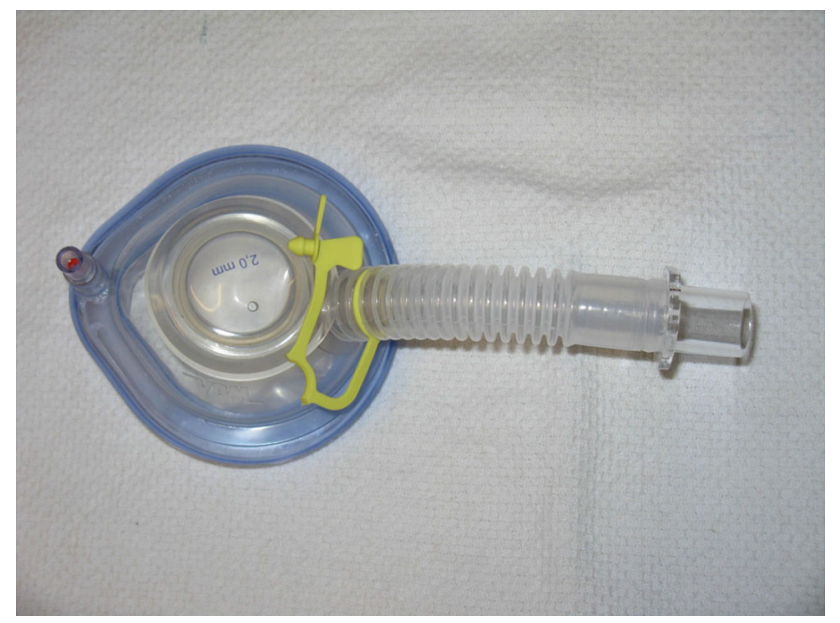

Fig. 7 Fibrescope intubating mask. The silicone diaphragm can be rotated to allow for oral or nasal intubation

Masque destiné à faciliter l'intubation par fibroscope. Le diaphragme de silicone peut être placé de façon à permettre l'intubation orale ou nasale help of experienced personnel. If bag-mask ventilation is easy or the patient is breathing spontaneously and has an unobstructed airway, anesthesia may be reversed, the child awakened, and the case performed as if the patient had an anticipated difficult airway. (Appendix 1, available as Electronic Supplementary Material). ${ }^{19}$ As long as ventilation and oxygenation are easily maintained, there is no reason for panic, and identical attempts at direct laryngoscopy should not be repeated. Instead, members of the OR team should have a calm discussion, and the most experienced airway experts should be available to help. It is well advised to spend an extra few minutes relying on bagmask ventilation while waiting for expert assistance. An SGA can be inserted to temporize, improve oxygenation, and free up the anesthesiologist's hands, but it must not be inserted at too light a plane of anesthesia. After discussion with the surgical team, it may be acceptable to proceed with the case using an SGA, provided that all necessary equipment and personnel needed to intubate the trachea will be available for the entire procedure. Otherwise, the abovementioned devices and techniques may be used to secure the airway.

If oxygenation and/or ventilation become inadequate during bag-mask ventilation, expert help must be requested immediately, including an otolaryngologist. Two-person bag-mask ventilation must be instituted, and if still inadequate, an SGA insertion should be attempted. If the SGA does not allow for adequate oxygenation, emergency invasive airway access in the form of a percutaneous or surgical cricothyroidotomy, rigid bronchoscopy, or surgical

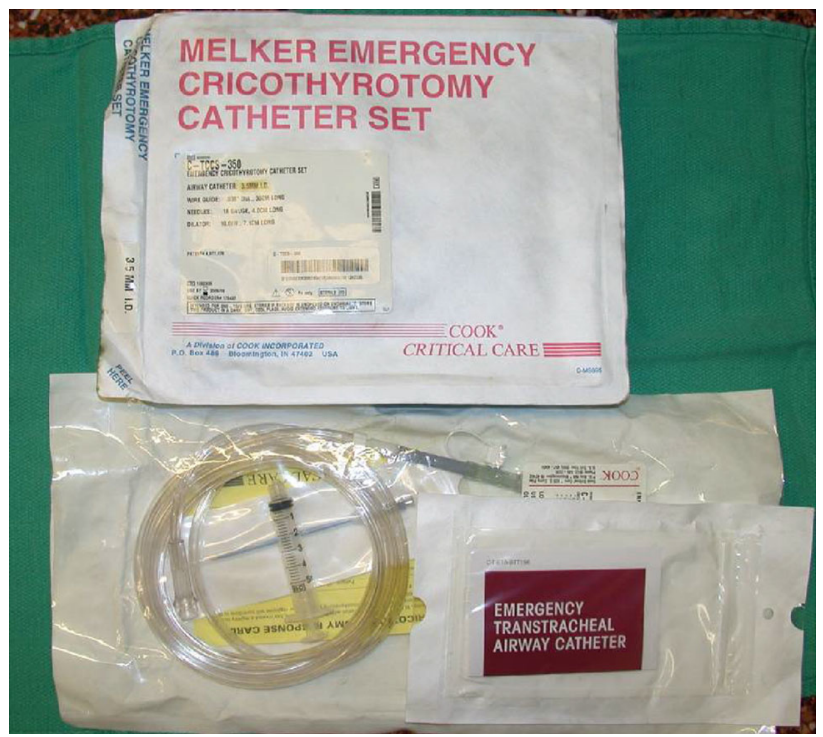

Fig. 8 Commercially prepared cricothyroidotomy and transtracheal jet ventilation kits

Trousses commerciales de cricothyroïdotomie et de jet-ventilation transtrachéale 


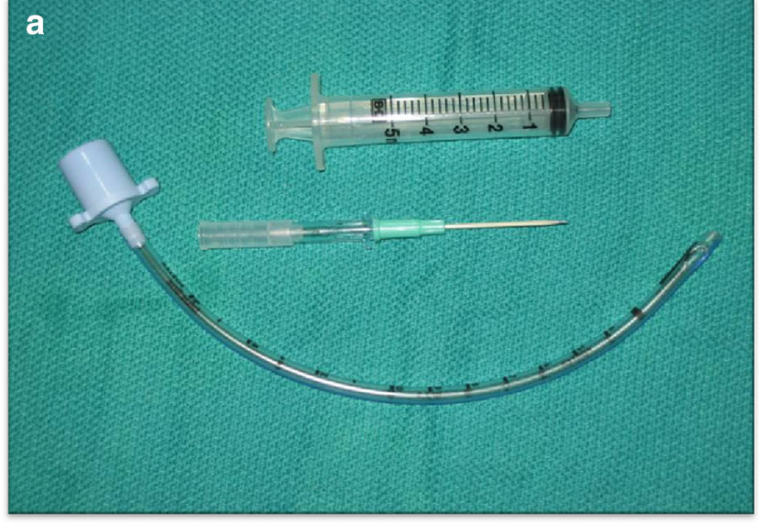

b

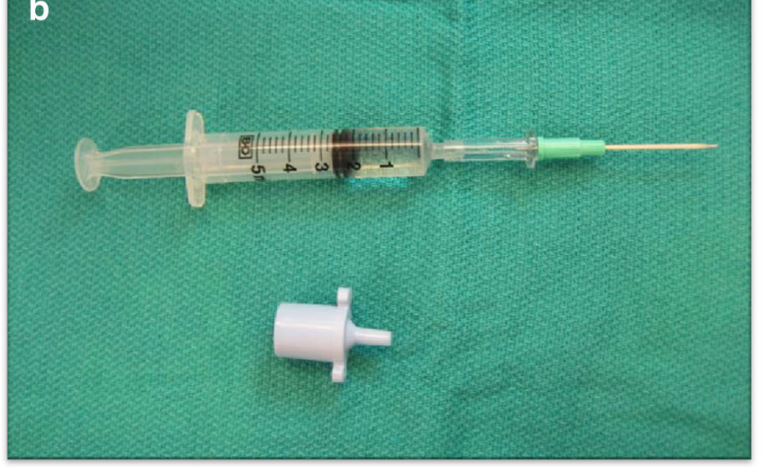

Fig. 9 Cricothyroidotomy set assembled from supplies found in most anesthetic carts. A syringe half filled with saline, an intravascular catheter, and a $15-\mathrm{mm}$ adapter from a tracheal tube that will fit snugly on a vascular catheter are assembled ( $a$ and $b$ ). The cricothyroid membrane is palpated and punctured with the vascular catheter (c). Aspiration of air confirms intratracheal placement (d). The $15-\mathrm{mm}$ tracheal tube adapter is attached to the catheter $(\mathrm{e}-\mathrm{g})$, allowing for emergency oxygenation until a definitive airway can be secured

tracheostomy is the next option, (Appendix 2, available as Electronic Supplementary Material). ${ }^{19}$ Cricothyroidotomy and transtracheal jet ventilation kits are commercially available (Fig. 8); however, a simple cricothyroidotomy kit can be constructed from equipment available in every anesthesia cart (Fig. 9).

\section{Conclusion}

With the ever increasing number of pediatric intubation devices entering the market, some of the tenets of pediatric difficult airway management are beginning to change. Despite these refinements, anesthesiologists would be wise to maintain the time-honoured skills of proper jaw thrust, two-person bag-mask ventilation, and direct laryngoscopy techniques unique to pediatric practice.
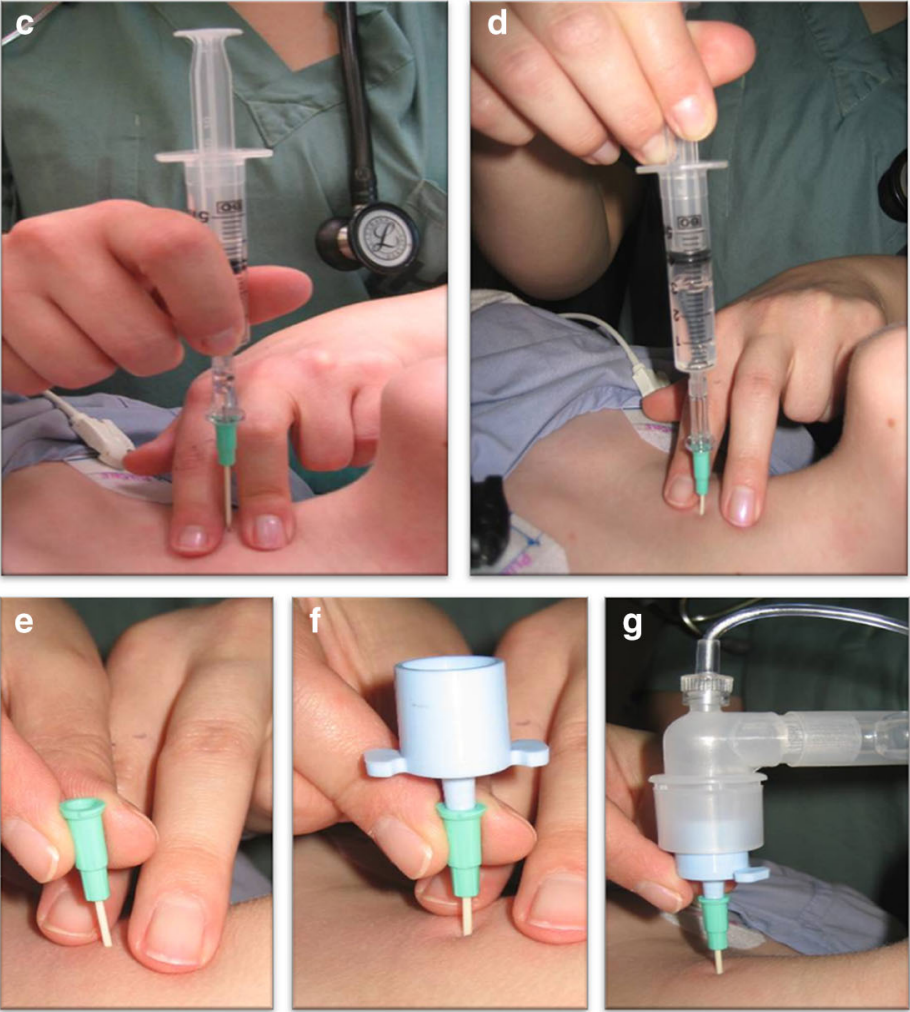

Trousse de cricothyroïdotomie assemblée à partir d'éléments présents dans la plupart des chariots d'anesthésie. Une seringue à moitié remplie de solution saline, un cathéter intravasculaire dans lequel l'adaptateur (15 mm) d'une sonde trachéale peut être inséré ( $\mathrm{a}$ et b). La membrane cricothyroïdienne est palpée et percée avec le cathéter (c). L'aspiration d'air confirme le positionnement dans la trachée (d). L'adaptateur de sonde trachéale de $15 \mathrm{~mm}$ est attaché au cathéter (e - g), ce qui permet une oxygénation d'urgence jusqu'à l'obtention d'un accès plus définitif aux voies aériennes

\section{Clinical scenario}

An eight-year-old male with Treacher Collins syndrome presents with testicular torsion confirmed by ultrasound. He had a tracheostomy as an infant which was reversed two years ago. He has since had three previous anesthetics for orthognathic procedures, all of which were described as "very difficult intubation", including one failed intubation and cancellation of surgery. The urologists would like to take the patient to the operating room emergently for exploration and orchidopexy. The patient is deaf and profoundly anxious. He is on nocturnal bilevel positive airway pressure (i.e., BiPAP) for severe obstructive sleep apnea.

On examination, the patient has typical features of Treacher Collins, including severe retrognathia, micrognathia, and mid-face hypoplasia. 
Instructions for completing the continuing professional development (CPD) module

1. Read the current article and the reference indicated in bold.

2. Go to: http://www.cas.ca/Members/CPD-Online and select the current module (Managing the challenging pediatric airway).

3. Answer the multiple choice questions regarding the case scenario.

4. Once you have entered all of your answers, you will have access to experts' explanations for all the possible choices.

5. Participants may claim up to four hours of CPD for a total of eight credits under Section 3 of the CPD program of the Royal College of Physicians and Surgeons of Canada.

\section{La prise en charge des voies aériennes difficiles chez l'enfant}

\section{Résumé}

Objectif Ce module permettra à l'anesthésiologiste d'identifier chez l'enfant les indices prédictifs d'une prise en charge difficile des voies aériennes ainsi que les moyens d'y faire face.

Constatations principales Bien que l'incidence d'intubation difficile soit inférieure en pédiatrie comparativement à la population adulte, l'anesthésiologiste qui prend soin d'enfants - même occasionnellement - doit être prêt à prendre en charge des voies aériennes connues comme difficiles ou susceptibles de l'être. Plusieurs des indices prédictifs d'intubation difficile utiles chez l'adulte ne s'appliquent pas à l'enfant. Sans surprise, plusieurs enfants difficiles à intuber sont atteints d'un syndrome ou ont un diagnostic souvent associé à une prise en charge difficile des voies aériennes.

En raison des caractéristiques émotionnelles, physiologiques et anatomiques propres aux enfants en bas âge, la prise en charge des voies aériennes diffère souvent de celle préconisée chez l'adulte. L'intubation vigile ou éveillée n'est pratiquement jamais une option; récemment, on observe une tendance vers l'utilisation de sondes trachéales à ballonnet et vers l'intubation en apnée. En raison de l'introduction récente de vidéolaryngoscopes spécialement conçus pour un usage pédiatrique, le fibroscope souple est désormais moins utilisé en tant que dispositif unique d'intubation. Les dispositifs supraglottiques sont maintenant utilisés chez les enfants présentant des voies aériennes difficiles, non seulement comme dispositif de sauvetage en cas d'échec d'intubation, mais également comme dispositif de premier choix et comme conduit pour l'intubation trachéale.

Conclusion Bien que la laryngoscopie directe puisse encore être utilisée chez la plupart des enfants présentant des voies aériennes difficiles, on observe aujourd'hui un recours croissant aux dispositifs supraglottiques et à l'intubation en apnée réalisée à l'aide de dispositifs à fibre optique ou de vidéolaryngoscopes.

\section{Objectifs de ce module de développement professionnel continu (DPC):}

Après avoir lu ce module, l'anesthésiologiste devrait être en mesure de:

1. Décrire les différences pertinentes d'un point de vue clinique entre les voies aériennes de l'enfant et de l'adulte;

2. Identifier les indices prédictifs d'une prise en charge difficile des voies aériennes chez l'enfant;

3. Prendre en charge de façon sécuritaire l'anesthésie d'un enfant présentant des voies aériennes difficiles;

4. Formuler un plan dans l'éventualité d'une intubation difficile imprévue ou d'un échec d'intubation chez un enfant.

La plupart des anesthésiologistes ne se spécialisant pas dans les soins pédiatriques se sentent à l'aise de prendre en charge des enfants de plus de huit ans - tant qu'il n'y a pas de comorbidités importantes. Ceci étant dit, l'anticipation de difficultés dans la prise en charge des voies aériennes constitue probablement la condition la plus susceptible d'altérer négativement leur confiance en leurs compétences. Ce module de développement professionnel continu aidera l'anesthésiologiste à identifier les voies aériennes difficiles chez l'enfant et à planifier l'induction de l'anesthésie dans de tels cas.

\section{Caractéristiques propres aux voies aériennes de l'enfant}

L'anatomie des voies aériennes d'un enfant possède des caractéristiques uniques qui pourraient rendre difficiles à la fois la ventilation au masque et l'intubation trachéale. Ces différences anatomiques sont décrites dans le tableau 1.

Certaines caractéristiques physiologiques et émotionnelles du patient pédiatrique peuvent avoir un impact sur la prise en charge des voies aériennes. En raison 
d'un métabolisme et d'un taux de consommation d'oxygène plus élevés, l'apnée provoque une désaturation rapide chez les nourrissons et les enfants en bas âge. L'enfant typique est anxieux, craintif et ne coopère pas. Un enfant qui pleure ou qui crie pendant l'induction désature encore plus rapidement. Pour cette raison, la sédation préopératoire et/ou la présence d'un parent est souvent bénéfique pendant l'induction, même si les voies aériennes sont présumées difficiles. ${ }^{1}$

Plusieurs écueils peuvent être rencontrés, même lors d'une prise en charge routinière des voies aériennes de l'enfant, particulièrement si l'anesthésiologiste n'est pas un spécialiste en pédiatrie. L'une des erreurs les plus fréquentes est l'identification tardive d'une obstruction des voies aériennes supérieures. Il convient de s'assurer que les voies aériennes de l'enfant sont véritablement dégagées pendant l'induction de l'anesthésie. Lorsqu'il y a obstruction des voies aériennes supérieures, la paroi thoracique compliante de l'enfant bouge énergiquement pendant la respiration spontanée. Il est important de réagir immédiatement pour soulager l'obstruction lorsqu'on observe l'un des signes suivants: déplacement caudal du cartilage thyroïde associé à l'inspiration ou «tracheal tug », mouvements paradoxaux de la paroi thoracique et absence de mouvement du ballon ventilatoire ou du tracé capnographique. Dans de nombreux cas, on peut soulager l'obstruction en provoquant une subluxation de la mâchoire avec une technique à deux mains et en exerçant une poussée antérieure de la tête de la mandibule (et non pas de l'angle). Chez un enfant en bas âge, une subluxation de la mâchoire mal réalisée pourrait exacerber l'obstruction en forçant la langue de l'enfant contre les palais durs et mous (voir vidéo 1, disponible sous forme de document électronique supplémentaire).

L'anesthésie trop légère pendant l'induction au masque ou la manipulation des voies aériennes est souvent source de difficultés. L'enfant partiellement anesthésié se débattra, retiendra son souffle ou développera une obstruction partielle des voies aériennes, ce qui provoquera rapidement une désaturation en oxygène. L'insertion d'une canule oropharyngée lorsque l'anesthésie est peu profonde peut également causer un laryngospasme ou l'arrêt respiratoire. Une anesthésie plus profonde facilite l'insertion de la canule oropharyngée pour soulager l'obstruction et assister ou prendre contrôle de la ventilation. Une ventilation au masque particulièrement vigoureuse, surtout lorsque l'anesthésie est peu profonde, peut provoquer une insufflation gastrique, réduisant les volumes pulmonaires et augmentant le risque de régurgitation. Une canule oropharyngée de la mauvaise taille peut constituer un facteur contributeur; lorsqu' on place une canule oropharyngée de la bonne taille à côté du visage de l'enfant, elle doit aller des lèvres jusqu'à l'angle de la mâchoire. La taille des dispositifs nasopharyngés se mesure du bout du nez jusqu'au tragus de l'oreille.

\section{Comment prévoir les difficultés de prise en charge des voies aériennes chez l'enfant?}

L'incidence d'intubation difficile chez l'enfant varie dans la littérature de moins de $0,1 \%$ à plus de $3,5 \%$. $^{2}$ Dans la plupart des centres, l'incidence la plus élevée est observée chez les nourrissons (moins d'un an) ${ }^{3}$ et les patients atteints d'anomalies cardiaques congénitales. ${ }^{4}$ Dans une étude unicentrique récente, l'incidence de laryngoscopie difficile était de $0,68 \%$, les nourrissons de moins d'un an et les adolescents présentant des anomalies cranio-faciales représentant la majorité des cas. ${ }^{5}$ Quoi qu'il en soit, il est clair que l'incidence d'intubation difficile est moindre chez l'enfant que chez l'adulte. Heureusement, la majorité des cas de voies aériennes difficiles chez l'enfant sont prévisibles si l'on tient compte des antécédents et de l'examen physique. De nombreux enfants présentant des antécédents d'intubation difficile souffrent d'un syndrome dont on connait le lien avec des voies aériennes difficiles.

Tableau 1 Caractéristiques anatomiques propres aux voies aériennes pédiatriques, implications cliniques et stratégies de prise en charge suggérées

\begin{tabular}{|c|c|c|}
\hline Caractéristique anatomique & Implication & Prise en charge \\
\hline Occiput proéminent & $\begin{array}{l}\text { Cou fléchi en position dorsale } \\
\text { Obstruction probable des voies aériennes supérieures } \\
\text { Les axes oral, pharyngé et laryngé ne sont pas alignés, } \\
\text { ce qui complique la laryngoscopie. }\end{array}$ & $\begin{array}{l}\text { Rouleau sous les épaules pour les } \\
\text { nourrissons (voir figure 1) }\end{array}$ \\
\hline $\begin{array}{l}\text { Larynx en position } \\
\text { céphalique }\end{array}$ & $\begin{array}{l}\text { Le larynx semble plus antérieur } \\
\text { La totalité de la langue est située dans la cavité orale, ce } \\
\text { qui augmente le risque d'obstruction }\end{array}$ & $\begin{array}{l}\text { Approche latérale pour la laryngoscopie } \\
\text { Dispositif oral pour soulager l'obstruction }\end{array}$ \\
\hline $\begin{array}{l}\text { L'épiglotte fait un angle } \\
\text { par dessus les cordes } \\
\text { vocales }\end{array}$ & L'épiglotte obstrue souvent la vue des cordes vocales & $\begin{array}{l}\text { Lame de laryngoscopie droite chez } \\
\text { l'enfant de moins de } 3 \text { ans }\end{array}$ \\
\hline
\end{tabular}


Tableau 2 Syndromes et conditions fréquemment associés à des difficultés dans la prise en charge des voies aériennes

\begin{tabular}{ll}
\hline Goldenhar & Arthrite juvénile \\
Pierre Robin & Fente palatine \\
Treacher Collins & Traumatisme/Brûlure \\
Arthrogrypose & Tumeur orale \\
Apert & Klippel-Feil \\
Trisomie 21 (Down) & Mucopolysaccharidoses \\
\hline
\end{tabular}

Le tableau 2 énumère certaines des conditions les plus fréquemment associées à une intubation difficile chez l'enfant. Bien que la laryngoscopie devienne, la plupart du temps, plus facile au fur et à mesure que l'enfant grandit, il existe toutefois d'importantes exceptions, notamment le syndrome de Goldenhar et les mucopolysaccharidoses, des conditions qui peuvent accentuer les difficultés d'intubation avec l'âge. ${ }^{6}$ Chez l'enfant de moins de quatre ans qui coopère, il a été démontré que le score de Mallampati était corrélé à la vue laryngoscopique de Cormack-Lehane. ${ }^{7}$ Toutefois, la majorité des enfants de ce groupe d'âge ne coopèrent pas et c'est pourquoi la plupart des praticiens considèrent la classification de Mallampati peu utile chez l'enfant. ${ }^{8}$ Un outil d'évaluation plus pratique consiste tout simplement à observer l'enfant de profil en cherchant à voir si la mâchoire paraît reculée ou plus petite que la norme ${ }^{2}$ (figure 2). Parmi les autres caractéristiques associées à une laryngoscopie difficile, citons une ouverture limitée de la bouche, une dentition proéminente, une asymétrie faciale accompagnée de déformations au niveau de l'oreille, et une fente palatine. ${ }^{9}$

\section{Prise en charge anesthésique}

\section{Préparation}

Indépendamment de la méthode d'induction et de prise en charge des voies aériennes prévues, une bonne préparation du patient et de l'équipement est essentielle. Un chariot dédié aux voies aériennes difficiles devrait être à portée de main et inclure tout le matériel nécessaire, incluant plusieurs lames de laryngoscope, dispositifs supraglottiques, guides de sonde trachéale, canules oropharyngées, trompettes nasales ainsi que fibroscopes et vidéolaryngoscopes. ${ }^{10}$ Il est tout aussi important d'obtenir l'aide d'un assistant possédant de l'expérience auprès des enfants que d'avoir à disposition un arsenal complet de dispositifs. Dans la mesure du possible, il faut installer un accès intraveineux avant l'induction chez un patient présentant des voies aériennes difficiles - mais seulement si les tentatives pour obtenir un accès vasculaire ne provoquent pas trop de stress supplémentaire et n'aggravent pas un accès déjà précaire aux voies aériennes. On peut faciliter la mise en place de cet accès à l'aide d'anesthésiques locaux topiques, tels que la crème EMLA ${ }^{\circledR}$ et le gel Ametop ${ }^{\mathrm{TM}}$, et de doses judicieuses d'anxiolytiques - si le patient est sous monitorage adéquat. ${ }^{11}$ Une dose de $0,5-1 \mathrm{mg} \cdot \mathrm{kg}^{-1}$ de midazolam avec $10-15$ $\mathrm{mg} \cdot \mathrm{kg}^{-1} \mathrm{~d}$ 'acétaminophène (qui dissimule le goût amer du midazolam) administrée par voie orale agit en une quinzaine de minutes. Les nourrissons de moins de $15 \mathrm{~kg}$ pourraient bénéficier d'une dose de $0,2-0,3 \mathrm{mg} \cdot \mathrm{kg}^{-1}$ de midazolam intranasal en vaporisateur, qui agit en cinq minutes. La solution intranasale de midazolam ne doit pas être diluée et être aussi concentrée que possible afin de minimiser le volume administré. Les agents anticholinergiques tels que l'atropine et le glycopyrrolate doivent être envisagés tant pour leurs propriétés antisialagogues que pour éviter la bradycardie associée à l'induction de l'anesthésie et la laryngoscopie. $^{12}$

Avant d'entrer en salle d'opération (SO), l'anesthésiologiste aura à l'esprit un plan d'action pour le déroulement de la séquence d'induction. Il est essentiel de planifier l'induction de l'anesthésie et de prévoir un plan de rechange et de partager le tout avec le personnel de la SO. Dans les situations très inquiétantes, il pourrait également être judicieux de communiquer d'avance avec l'otorhinolaryngologiste.

\section{Stratégies d'induction}

Le maintien d'une oxygénation et d'une ventilation adéquates est essentiel tout au long de la séquence d'intubation. Parce que la désaturation en oxygène est très rapide chez les jeunes enfants rendus apnéiques, le maintien de la respiration spontanée pendant l'intubation trachéale constitue la méthode traditionnelle de prise en charge de voies aériennes difficiles. Un dispositif de ventilation nasopharyngé ou une petite sonde trachéale insérée dans le nasopharynx peut agir à titre de conduit pour l'oxygène (et les agents anesthésiques par inhalation) pendant les tentatives d'intubation. Chez les nourrissons et les jeunes enfants, il a été démontré qu'administrer de l'oxygène $\left(2-5 \mathrm{~L} \cdot \mathrm{min}^{-1}\right)$ via des lunettes nasales pendant l'apnée améliore l'oxygénation, ce qui donne le temps crucial nécessaire pour accéder aux voies aériennes. ${ }^{12} \mathrm{La}$ décision de maintenir la respiration spontanée pendant l'intubation dépend de facteurs propres au patient, des habitudes institutionnelles, et de la préférence personnelle de l'anesthésiologiste. Des conditions telles que les tumeurs intra-orales ou médiastinales, l'épiglottite, les corps étrangers dans les voies aériennes et l'ouverture de la bouche très limitée peuvent être associées à une ventilation au masque difficile ou risquée. Chez ces patients, il peut être avisé d'éviter la ventilation en pression positive et la relaxation musculaire jusqu'à l'obtention du contrôle des 
voies aériennes et/ou de la levée de l'obstruction. L'induction de l'anesthésie peut se faire par l'inhalation de sévoflurane, par perfusion anesthésique intraveineuse, ou en associant ces deux méthodes. À cet effet, on peut utiliser diverses combinaisons de propofol, de kétamine, de midazolam et de rémifentanil.

On observe une tendance croissante vers l'intubation trachéale apnéique, voire la curarisation, lorsqu'on prend en charge des voies aériennes difficiles chez l'enfant - si la ventilation au masque est aisée. Cette tendance est en partie due à l'introduction de divers vidéolaryngoscopes destinés spécifiquement à l'usage pédiatrique. À l'époque où le fibroscope souple était le seul dispositif disponible sur le marché, l'approche logique voulait qu'on maintienne la respiration spontanée pendant l'intubation trachéale. Par rapport à la laryngoscopie directe, la vidéolaryngoscopie peut accélérer et favoriser une meilleure visualisation glottique; on observe en outre un taux plus élevé d'intubations réussies chez les enfants présentant des voies aériennes difficiles avec cette technique. ${ }^{13}$ Ces dispositifs ont permis aux anesthésiologistes d'envisager avec plus de confiance le recours à l'apnée lors de la prise en charge des voies aériennes difficiles. Quel que soit le dispositif d'intubation, les anesthésiologistes doivent être rompus à son utilisation chez l'enfant présentant des voies aériennes normales avant de l'utiliser dans les cas difficiles. La préférence de l'auteur va à l'intubation en apnée, mais seulement si la ventilation au masque se fait sans encombre et en excluant les conditions déjà mentionnées, pour lesquelles une curarisation serait risquée. Il convient d'être toujours prêt à maintenir l'oxygénation et la ventilation en pression positive au cas où l'intubation trachéale échouerait. Pour ce faire, la technique de ventilation au masque à deux personnes (voir figure 3) devrait être appliquée entre les tentatives, et des dispositifs de sauvetage oraux et supraglottiques de tailles adaptées devraient être disponibles.

L'utilisation du sugammadex pourrait influencer l'approche de l'anesthésiologiste lors de la prise en charge d'un enfant présentant des voies aériennes difficiles. À l'heure actuelle, le sugammadex est commercialisé dans plus de 40 pays, et des comptes rendus ont montré qu'il peut rapidement neutraliser une paralysie profonde réalisée avec du rocuronium chez l'enfant. ${ }^{14}$ À ce jour toutefois, le sugammadex n'est pas breveté au Canada, en raison en partie de son coût exorbitant. On estime qu'il en coûte plus de $540 \$$ pour neutraliser un bloc profond au rocuronium chez l'adulte typique.

Bien que la panoplie de dispositifs d'intubation à fibre optique et de vidéolaryngoscopes destinés à un usage pédiatrique soit vaste et ne cesse de s'étendre, la majorité des intubations trachéales chez l'enfant présentant des voies aériennes difficiles peuvent être réalisées par laryngoscopie directe. La technique d'intubation trachéale à deux suggère qu'une personne réalise la laryngoscopie et manipule le larynx jusqu'à sa visualisation, pendant qu'un second opérateur regarde par dessus l'épaule du « laryngoscopiste » et insère la sonde trachéale avec stylet ou broche guide. Cette technique ne nécessite aucun équipement spécial ou dispendieux et affiche un taux de réussite très élevé lorsqu'elle est réalisée par du personnel d'expérience (figure 4). Il s'agit d'une technique utile à maîtriser comme stratégie d'intubation de rechange ou si les dispositifs à fibre optique ou vidéolaryngoscopes ne sont pas disponibles.

Les sondes trachéales avec ou sans ballonnet

Au cours de la dernière décennie, on a observé une tendance claire vers l'utilisation de sondes trachéales avec ballonnet chez l'enfant. Cette tendance est en grande partie liée à l'introduction de ballonnets à basse pression et haut volume. Un compte rendu récent a confirmé la domination croissante des sondes à ballonnet dans la pratique de l'anesthésie pédiatrique. ${ }^{15} \mathrm{Il}$ a également été démontré que leur utilisation réduisait le nombre de tentatives d'intubation, diminuait les coûts et n'entrainait que peu d'effets secondaires. Il faut éviter d'avoir à 'deviner' la taille de la sonde trachéale chez l'enfant présentant des voies aériennes difficiles, particulièrement s'il y a un risque que celle-ci soit trop large pour passer à travers le cartilage cricoïde. En tant que tel, la tendance est de préférer une sonde légèrement plus petite, ce qui accentue l'avantage des sondes à ballonnet. Le seul inconvénient de cette approche est qu'une sonde plus petite entraîne l'usage d'un stylet de plus petite taille et plus fragile ou d'un fibroscope souple, aussi plus petit, avec une qualité optique inférieure.

\section{Dispositifs pour les voies aériennes}

Un nombre impressionnant de dispositifs pour les voies aériennes adaptés à une utilisation pédiatrique est désormais disponible. Ces dispositifs sont des versions miniatures d'instruments conçus à l'origine pour un usage adulte. Ils comprennent des outils supraglottiques, des fibroscopes souples, des vidéolaryngoscopes et laryngoscopes optiques, et des stylets lumineux avec fibre optique. Certains sont fragiles et nécessitent un entretien fréquent, et tous sont relativement dispendieux. On observe une tendance à encourager les médecins résidents à utiliser l'un de ces dispositifs plutôt qu'un laryngoscope direct. Cette tendance est compréhensible étant donné la dimension pédagogique qu'un écran de visionnement procure, tant pour l'élève que pour l'enseignant. Chaque dispositif est toutefois accompagné d'une courbe d'apprentissage, et il convient d'enseigner aux débutants les techniques de subluxation mandibulaire et de ventilation au masque spécifiques aux populations pédiatriques. Étant donné que certains centres 
ne possèdent pas ces nouveaux instruments d'intubation, la laryngoscopie directe doit demeurer une partie essentielle de tout programme de formation visant la prise en charge des voies aériennes chez l'enfant. Les sections suivantes décrivent les différences notoires dans la prise en charge des voies aériennes difficiles chez l'enfant à l'aide de divers dispositifs.

\section{Les dispositifs supraglottiques}

Tous les anesthésiologistes expérimentés ont probablement déjà utilisé un dispositif supraglottique chez un patient avec des difficultés connues au niveau des voies aériennes. Ces dispositifs ont révolutionné la pratique de l'anesthésie et occupent à juste titre un rôle très important dans tout algorithme de voies aériennes difficiles. Un dispositif supraglottique pourrait être le premier choix pour la prise en charge d'un enfant présentant des voies aériennes connues ou présumées difficiles si les conditions suivantes sont respectées: les voies aériennes sont accessibles en tout temps, la ventilation et l'oxygénation sont faciles à maintenir, et un plan alternatif a été formulé et transmis à toute l'équipe de la SO. Dans l'idéal, la chirurgie doit être de nature périphérique et s'avérer de courte durée. L'opération ne devrait pas causer de transferts liquidiens importants et devrait être réalisée en position de décubitus dorsal. Un dispositif supraglottique n'est probablement pas le meilleur choix si les voies aériennes sont obstruées en deçà de la glotte, si la ventilation nécessite une pression élevée ou si le risque d'aspiration pulmonaire est significatif. ${ }^{16}$ Bon nombre des dispositifs supraglottiques récents présentent un diamètre plus large, un conduit moins long et moins angulé afin de permettre l'intubation via la lumière ventilatoire. Dans une importante étude unicentrique rétrospective, un dispositif supraglottique constituait le premier choix pour la prise en charge de voies aériennes difficiles chez $23 \%$ des enfants. D'autres instruments ne se sont avérés nécessaires que chez quatre de ces patients; chez deux patients, on a remplacé le dispositif supraglottique par un autre dispositif supraglottique d'une taille différente, et chez deux autres, le dispositif a servi de conduit pour réaliser une intubation trachéale avec fibroscope. ${ }^{17}$ Dans la mesure du possible, il convient de s'exercer à pratiquer l'intubation par fibroscope via un dispositif supraglottique sur un mannequin avant de tenter cette intervention chez un enfant. Cette technique nécessite plusieurs étapes coordonnées qui ne peuvent être interrompues ou retardées, et s'avère encore plus compliquée avec une sonde trachéale à ballonnet. L'intubation par fibroscope via un dispositif supraglottique chez l'enfant est décrite dans la littérature. ${ }^{1}$ Il est souvent plus facile de réaliser une intubation fibroscopique via un dispositif supraglottique si le patient est apnéique et en anesthésie profonde (ou même curarisé) au moment où le fibroscope passe à travers les cordes vocales. Le clinicien peut évaluer, via le fibroscope, si l'ouverture glottique est bien visible lorsqu'il atteint l'extrémité distale du dispositif supraglottique et recourir alors à la paralysie ou à l'anesthésie profonde afin de minimiser le risque de laryngospasme ou de toux lorsque le fibroscope traverse les cordes. Si toutefois les cordes vocales n'étaient pas situées immédiatement devant l'ouverture du dispositif supraglottique, il conviendrait alors d'ajuster la position du dispositif afin d'obtenir une vue sans obstruction de l'ouverture glottique. Si le chemin reliant le dispositif supraglottique à la glotte s'avère sinueux, on réduit alors la probabilité de glisser facilement la sonde trachéale sur le fibroscope.

\section{Les laryngoscopes directs}

Étant donné que les voies aériennes difficiles peuvent être prises en charge par laryngoscopie directe chez la vaste majorité des enfants, la maîtrise de cette technique est la deuxième compétence la plus importante à acquérir (la première étant la réalisation de la subluxation mandibulaire combinée à la ventilation au masque adaptée chez l'enfant). Il faut tenir compte de la taille de la mâchoire de l'enfant, plutôt que de son âge ou son poids, lorsqu' on choisit la lame du laryngoscope. Un patient de 18 ans pesant $80 \mathrm{~kg}$ et atteint d'un syndrome de Goldenhar et de micrognathie grave est mieux servi par une lame de laryngoscope adaptée à la taille de sa mâchoire, qui est souvent celle destinée au nourrisson. En fait, parmi toutes les tailles et formes de lames différentes, la lame droite de taille 1 (celle conçue pour les nourrissons) offre bien souvent la meilleure vue laryngoscopique chez un patient présentant une micrognathie/rétrognathie. La lame est insérée à l'extrémité droite de la bouche et n'est pas glissée vers le centre, comme c'est le cas chez l'adulte. Ainsi, on garde la langue à gauche de la lame en tout temps et on empêche que les incisives et les canines n'obstruent la vue (figure 5). Il peut être utile d'avoir un assistant qui étire la commissure labiale avec un petit écarteur (par ex., un écarteur Senn) afin d'augmenter l'espace pour l'insertion de la sonde trachéale. La sonde endotrachéale avec stylet doit être droite ou en forme de bâton de hockey. Dans l'idéal, tous les cas d'intubation difficile devraient être pris en charge avec une technique à deux personnes telle que précédemment décrite.

Les guides pour l'introduction de la sonde trachéale (bougies)

Bien que certaines présentations de cas décrivent une intubation réussie avec une bougie chez l'enfant, ${ }^{18}$ la 
valeur de cette stratégie dans la prise en charge de voies aériennes difficiles en pédiatrie est moindre que chez l'adulte. Le diamètre réduit des bougies pédiatriques les rend très fragiles. Chez les nourrissons et les enfants en bas âge, il est quasiment impossible de sentir les anneaux trachéaux lors de l'insertion de la pointe de la bougie dans la trachée. Autrement dit, la bougie ne peut être utilisée de la façon prévue; plutôt, elle est insérée dans l'oropharynx sous la lame du laryngoscope. Si on rencontre une résistance à une distance coïncidant à la position anticipée de la carène, on suppose alors que la bougie est dans la trachée. Si on ne rencontre pas de résistance, alors il est probable qu'elle soit dans l'œsophage. Bon nombre d'anesthésiologistes hésitent à recourir à une technique à l'aveugle pour intuber la trachée d'un enfant alors qu'il existe d'autres options qui permettent de visualiser la glotte.

\section{Les vidéolaryngoscopes}

Plusieurs vidéolaryngoscopes sont disponibles pour un usage chez le nourrisson et l'enfant. La plupart des médecins résidents en anesthésiologie connaissent bien leur utilisation chez l'adulte, et bon nombre des compétences requises pour l'intubation par vidéolaryngoscopie chez l'adulte s'appliquent chez l'enfant - malgré quelques exigences spécifiques. Étant donné qu'un jeune enfant apnéique désature rapidement, l'insertion de la sonde trachéale avec stylet du côté droit de la bouche en direction de l'hypopharynx avant l'insertion du vidéolaryngoscope peut être doublement utile. En premier lieu, on réduit ainsi le risque de ne pas pouvoir insérer la sonde trachéale dans l'oropharynx pendant la vidéolaryngoscopie, un problème fréquent chez l'adulte. Deuxièmement, cette méthode épargnera des secondes précieuses nécessaires à diriger la pointe de la sonde jusqu'au larynx, étant donné qu'elle sera probablement proche de celui-ci lors de l'insertion du vidéolaryngoscope (vidéo 2 , disponible comme document électronique supplémentaire). Bien que les fabricants de ces sondes recommandent un stylet en forme de lame, plusieurs préfèrent une configuration en bâton de hockey. Dans le cas d'un larynx très antérieur ou de rétro-/micrognathie grave, le fait d'exagérer la courbe du « bâton de hockey » au-delà de $90^{\circ}$ peut s'avérer utile (figure 6). Il convient d'utiliser le stylet le plus grand et le plus rigide possible, un stylet souple étant de peu d'utilité. Une autre astuce consiste à créer le plus d'espace possible entre la pointe du vidéolaryngoscope et les cordes vocales. On peut ainsi manipuler plus facilement la sonde trachéale avec stylet lorsqu'elle s'approche de la glotte. Le vidéolaryngoscope est inséré au centre de bouche, et lorsqu'on voit la glotte, il convient de le retirer en direction céphalique pour créer l'espace nécessaire au positionnement de la pointe de la sonde trachéale dans la glotte.
Le vidéolaryngoscope peut aussi faciliter l'intubation avec un fibroscope souple, que ce soit à des fins d'enseignement ou dans l'éventualité d'un échec avec l'un ou l'autre de ces instruments utilisés seuls. Les personnes particulièrement intéressées à la prise en charge de voies aériennes difficiles privilégient cette technique, laquelle nécessite les efforts coordonnés d'opérateurs expérimentés ayant pratiqué cette manœuvre sur des voies aériennes normales. Dans ce cas, l'éclairage et l'image proviennent tous deux du vidéolaryngoscope, et le fibroscope joue simplement le rôle d'un stylet ajustable (vidéo 3, disponible comme document électronique supplémentaire).

\section{Les fibroscopes souples}

Malgré la quantité de vidéolaryngoscopes et de laryngoscopes optiques disponibles sur le marché, le fibroscope souple va probablement garder encore longtemps sa place privilégiée dans tous les départements d'anesthésie. Comme mentionné plus haut, il peut être combiné à d'autres dispositifs de prise en charge des voies aériennes afin d'optimiser les conditions d'intubation. De plus, on aura toujours besoin, à l'occasion, de regarder à l'intérieur de la sonde trachéale à des fins diagnostiques ou thérapeutiques. La bronchoscopie par fibroscope souple demeure la méthode de choix pour les intubations difficiles pour de nombreux anesthésiologistes qui sont passés maitres dans son utilisation.

Plusieurs astuces sont proposées pour favoriser une intubation trachéale rapide et sécuritaire avec un fibroscope souple. Premièrement, il faut garantir une bonne oxygénation tout au long du processus. Comme mentionné plus haut, une petite sonde trachéale placée dans le nasopharynx peut servir de conduit pour l'oxygène et les agents inhalés chez un enfant respirant spontanément. Sinon, de l'apport d'oxygène via des lunettes nasales peut procurer, de façon provisoire, une oxygénation satisfaisante, et ce, que le patient respire ou non. Les masques d'intubation fabriqués dans le commerce permettent d'appliquer une pression ventilatoire positive tout en réalisant une intubation orale ou nasale (figure 7). Indépendamment de l'approche, il est toujours recommandé de faire passer la pointe du fibroscope dans le pharynx et audelà des cordes vocales aussi rapidement que possible. Cela est particulièrement vrai si on a choisi une technique d'intubation en apnée. Lorsque la sonde trachéale est chargée sur le fibroscope et que l'assistant procède à la ventilation pulmonaire, le fibroscope est placé à côté du visage du patient, la pointe courbée vers l'avant. L'anesthésiologiste tient le fibroscope afin que la pointe de celui-ci avoisine les cordes vocales (plus ou moins à l'angle de la mâchoire). Son index et son pouce tiennent le fibroscope là où les doigts touchent les lèvres du patient (en cas d'intubation orale) ou les narines (en cas d'intubation nasale). Le fibroscope est ensuite placé dans la bouche ou le nez du patient, en suivant la ligne 
médiane avec la pointe fléchie antérieurement. Il est rapidement avancé jusqu'à ce que les doigts de l'anesthésiologiste touchent le patient. Alors seulement l'anesthésiologiste doit regarder l'écran pour procéder aux derniers ajustements nécessaires à l'insertion de la sonde dans la glotte. Cette approche permet de minimiser le temps nécessaire à l'insertion jusqu' aux aux cordes vocales. Avec un peu de pratique, cette technique permet de réaliser une intubation trachéale en quelques secondes seulement. Les vidéos 4 et 5 illustrent cette technique sur un mannequin et sur un enfant (disponibles comme documents électroniques supplémentaires).

Les difficultés imprévues dans la prise en charge des voies aériennes

En cas d'intubation difficile imprévue, l'anesthésiologiste doit agir rapidement et calmement et demander l'aide de personnel d'expérience. Si la ventilation au masque est facile, si le patient respire spontanément et que ses voies aériennes ne sont pas obstruées, on peut réveiller l'enfant et reprendre le cas sachant que les voies aériennes sont maintenant connues difficiles (annexe 1, disponible comme document électronique supplémentaire). ${ }^{19}$ Tant qu'il est facile de maintenir la ventilation et l'oxygénation, il n'y a pas de raison de paniquer, et de multiples laryngoscopies directes identiques doivent être évitées. Plutôt, les membres de l'équipe de SO doivent discuter calmement, et les experts des voies aériennes avec le plus d'expérience être disponibles pour fournir de l'aide au besoin. Il est préférable de continuer la ventilation au masque quelques minutes de plus si l'arrivée d'experts est prévue. Un dispositif supraglottique peut être mis en place pour gagner du temps, améliorer l'oxygénation, et libérer les mains de l'anesthésiologiste, mais il ne doit pas être inséré si l'anesthésie n'est pas assez profonde. Après avoir discuté avec l'équipe chirurgicale, il peut être acceptable de continuer le cas avec un dispositif supraglottique, mais il faut que tout l'équipement et le personnel nécessaire pour intuber la trachée soient disponibles tout au long de l'intervention. Autrement, on peut utiliser les dispositifs et techniques décrits ci-dessus pour garantir l'accès aux voies aériennes.

Si la ventilation au masque devient problématique ou ne permet plus de maintenir l'oxygénation, il faut immédiatement demander l'aide d'experts, incluant la présence d'un otorhinolaryngologiste. La ventilation au masque doit alors s'effectuer à deux personnes et, en l'absence d'amélioration, il faut tenter d'insérer un dispositif supraglottique. Si le dispositif supraglottique ne permet pas une oxygénation satisfaisante, la prochaine étape consiste à aborder d'urgence les voies aériennes de manière invasive à l'aide d'une cricothyrö̈dotomie percutanée ou chirurgicale, d'une bronchoscopie rigide ou d'une trachéostomie chirurgicale (annexe 2, disponible comme document électronique supplémentaire). ${ }^{19}$ Des trousses de cricothyroïdotomie et de jet-ventilation transtrachéale sont disponibles dans le commerce (figure 8); toutefois, une simple trousse de cricothyroïdotomie peut être assemblée à partir d'éléments disponibles dans tous les chariots d'anesthésie (figure 9).

\section{Conclusion}

En raison du nombre toujours croissant de dispositifs d'intubation pédiatriques sur le marché, certains principes visant la prise en charge de voies aériennes difficiles chez l'enfant sont en train de changer. Malgré ces améliorations techniques il est important pour les anesthésiologistes de maintenir les compétences nécessaires à la réalisation de la subluxation mandibulaire, de la ventilation au masque à deux personnes, et des techniques de laryngoscopie directe propres à la pratique pédiatrique.

\section{Cas clinique}

Un garçonnet de huit ans atteint du syndrome de Treacher Collins se présente avec une torsion testiculaire confirmée par échographie. Il a subi une trachéostomie lorsqu'il était nourrisson, laquelle s'est refermée il y a deux ans. Depuis, il a subi trois anesthésies pour des interventions orthognatiques, toutes caractérisées par des intubations qualifiées de «très difficiles », incluant un cas où l'échec d'intubation a entraîné l'annulation de la chirurgie. Les urologues aimeraient conduire d'urgence le patient en salle d'opération pour procéder à une exploration doublée d'une orchidopexie. Le patient est sourd et très anxieux. Il souffre d'apnée du sommeil sévère traitée par l'emploi de ventilation nocturne sous forme de BiPAP.

Lors de l'examen, le patient présente les caractéristiques typiques du syndrome de Treacher Collins, notamment une rétrognathie extrême, une micrognathie, et une hypoplasie médiane du massif facial.

\section{Directives pour compléter le module de développement professionnel continu (DPC)}

1. Lisez cet article et la référence en gras.

2. Allez à: http://www.cas.ca/Membres/modules-de-DPC et sélectionnez le module actuel (La prise en charge des voies aériennes difficiles chez l'enfant).

3. Répondez aux questions à choix de réponses concernant le cas clinique. 
4. Une fois que vous avez saisi toutes vos réponses, vous aurez accès aux explications d'experts pour tous les choix possibles.

5. Les participants peuvent réclamer un maximum de quatre heures de DPC pour un total de huit crédits sous la Section 3 du programme de DPC du Collège royal des médecins et chirurgiens du Canada.

Funding sources No funding sources.

Conflicts of interest No conflicts of interest to report.

Sources de financement Aucune source de financement.

Conflit d'intérêt Aucun.

\section{References}

1. Walker RM, Ellwood J. The management of difficult intubation in children. Pediatr Anesth 2009; 19: 77-87.

2. Sunder RA, Haile DT, Farrell PT, Sharma A. Pediatric airway management: current practices and future directions. Pediatr Anesth 2012; 22: 1008-15.

3. Heinrich S, Birkholz T, Ihmsen H, Irouschek A, Ackermann A, Schmidt $J$. Incidence and predictors of difficult laryngoscopy in 11,219 pediatric anesthesia procedures. Pediatr Anesth 2012; 22: 729-36.

4. Heinrich S, Birkholz T, Ihmsen H, et al. Incidence and predictors of poor laryngoscopic view in children undergoing pediatric cardiac surgery. J Cardiothorac Vasc Anesth 2013; 27: 516-21.

5. Karsli C, Matthew P, Pehora C, Al-Izzi A, Kianafraz K, Ponte A. Pediatric difficult airway management in a tertiary care centre. Can J Anesth 2015; 62(Suppl): 82398 (abstract).

6. Bew S. Managing the difficult airway in children. Anaesthesia \& Intensive Care Medicine 2006; 7: 172-5.
7. Santos AP, Mathias LA, Gozzani JL, Watanabe M. Difficult intubation in children: applicability of the Mallampati index (Portuguese, Spanish). Rev Bras Anestesiol 2011; 61: 156-8.

8. Kopp VJ, Bailey A, Valley RD, et al. Utility of the Mallampati classification for predicting difficult intubation in paediatric patients. Anesthesiology 1995; 83: A1146.

9. Engelhardt $T$, Weiss $M$. A child with a difficult airway: what do I do next? Curr Opin Anaesthesiol 2012; 25: 326-32.

10. Karsli C, Isaac LA. Induction of anesthesia. In: Bissonnette B (Ed.): Pediatric Anesthesia: Basic Principles, State-of-the-Art, Future. PMPH - USA; 2011: 669-89.

11. Hall $S C$. The difficult pediatric airway - recognition, evaluation, and management. Can J Anesth 2001; 48: R1-5.

12. Weingart SD, Levitan RM. Preoxygenation and prevention of desaturation during emergency airway management. Ann Emerg Med 2012; 59(165-75): e1.

13. Sun $Y, L u Y$, Huang $Y$, Jiang $H$. Pediatric video laryngoscope versus direct laryngoscope: a meta-analysis of randomized controlled trials. Paediatr Anaesth 2014; 24: 1056-65.

14. Plaud B, Meretoja O, Hofmockel R, et al. Reversal of rocuronium-induced neuromuscular blockade with sugammadex in pediatric and adult surgical patients. Anesthesiology 2009; 110: 284-94.

15. Crankshaw D, McViety J, Entwistle M. A review of cuffed vs uncuffed endotracheal tubes in children. Pediatric Anesthesia and Critical Care Journal 2014; 2: 70-3.

16. Asai $T$. Is it safe to use supraglottic airway in children with difficult airways? Br J Anaesth 2014; 112: 620-2.

17. Jagannathan N, Sequera-Ramos L, Sohn L, Wallis B, Shertzer A, $S c h a l d e n b r a n d K$. Elective use of supraglottic airway devices for primary airway management in children with difficult airways. $\mathrm{Br}$ J Anaesth 2014; 112: 742-8.

18. Arora $M K$, Karamchandani $K$, Trikha A. Use of a gum elastic bougie to facilitate blind nasotracheal intubation in children: a series of three cases. Anaesthesia 2006; 61: 291-4.

19. The Association of Paediatric Anaesthetists of Great Britain and Ireland. Paediatric Difficult Airway Guidelines, 2012. Available from URL: http://www.apagbi.org.uk/publications/apa-guidelines (accessed March 2015). 